\title{
The Efficacy of Eco-friendly Botanicals in the Management of Damping-off and Downy Mildew Diseases of Cucumber
}

\author{
Utobo E.B. ${ }^{1}$, Ekwu L.G. ${ }^{2}$, Nwogbaga, A.C. ${ }^{3}$, Nwanchor, K. ${ }^{4}$ \\ Department of Crop Production and Landscape Management, Faculty of Agriculture and Natural Resources Management, Ebonyi State \\ University, P.M.B. 053 Abakaliki, Nigeria
}

\begin{abstract}
Experiments were conducted in 2011 and 2012 cropping seasonsunder field conditions to investigate the possible utilization of plant material extracts to manage damping-off and downy mildew diseases of cucumber. Three plant materials, i.e. ginger rhizomes, garlic bulbs, and neem leaves were extracted using water, at three different concentrations $(4,8$, and $12 \%)$, and tap water was used as a check.The results (combined for the two years) revealed that cucumber seeds treated with different plant material extracts at various concentrations significantly reduced the pre-and post-emergence damping-off diseasesand increasedthe survival counts relative to control. From 4 weeks after planting, cucumber plants responded positively to weekly sprays of different plant extracts at all concentration tested and significantly suppressed the incidenceand severity of downy mildew disease and thus enhanced the relative disease control. This resulted in improved growth and yield of cucumber plants when compared tocheck.The degree of effectiveness of plant extracts in the management of damping-off and downy mildew diseases of cucumber were: ginger > neem > garlic and the most effective concentration level in this regard was $8 \%$.
\end{abstract}

Keywords: Cucumber, damping-off, downy mildew, botanicals, eco-friendly,

\section{Introduction}

Cucumber production in Nigeria is fast becoming popular since it is a useful ingredient in the preparation of salads and liquor drinks at homes and hostels [1].There are many factors responsible for the low yield of cucumber crop production and among them fungal diseases play an important role. Among the various fungal diseases, Sclerotium rolfsii, Fusarium oxysporium and Rhizoctonia solani causing damping-off disease and Pseudoperonospora cubensiscausing downy mildew disease are among the most destructive pathogens that attack this vegetable crop [2]. Thesepathogens cause considerable losses in yields in the field and greenhouse all over the world [3] including Nigeria.Chemical fungicides have been used as the main strategy for control of these fungal diseases and subsequently increasecrop production.Unfortunately, the overzealous and indiscriminate use of most of the synthetic fungicides has created different types of environmental and toxicological problems [4]. The development and utilization of ecofriendly botanicalalternative have been the main focus of researchers and environmentalists, due to public concern over the toxicity and environmental impact of these conventional synthetic pesticides [5]. Hence, newer approaches are being explored and one important option is the use of botanical pesticides.Pesticides derived from natural sources support both crop production and the environment by being effective in the plant pathogen management, biodegradable, and are safer than synthetic fungicides [5].Fortunately, thousands of these phytochemicals have proved to have inhibitory effects on all types of microorganisms in vitro[4]. Gurjar et al. [4] reported that these plant extracts should be subjected to in vivo testing to evaluate their efficacy in controlling the incidence of diseases in crops and plants. The present study wastherefore designed toinvestigate the efficacy of aqueous extract of different plant material at various concentrations in the management of damping-off and downy mildew diseases of cucumber in Abakaliki, South Eastern Nigeria.

\section{Materials and Methods}

\subsection{Experimental Site}

The study was conducted at the Teaching and Research Farm of the Department of Crop Production and Landscape Management, Ebonyi State University, Abakaliki, in the derived savannah zone of South Eastern Nigeria $\left(06^{0} 45^{\prime} \mathrm{N}\right.$, $08^{0} 30^{\prime} \mathrm{E}, 447 \mathrm{~m}$ above the sea level), during 2011 and 2012 cropping seasons respectively. The climate is characterized with daily temperature range of $22^{\circ} \mathrm{C}$ to $32^{\circ} \mathrm{C}$, and has a bimodal rainfall pattern from April to November with a peakin August and September. The total rainfall ranges from $1700 \mathrm{~mm}-2000 \mathrm{~mm}$ with a mean of $1800 \mathrm{~mm}$ and in the form of an intensive violent shower of short duration (EBADEP, 2005). The soil belongs to the order utisol which is largely loamy and ranging from medium to high fertility, indicating suitability for agriculture[6].

\subsection{Experimental design and treatments}

The experiment was conducted as a $4 \times 3$ factorial laid out in a Randomized Complete Block Design (RCBD) with three replicates of each treatment. Each replicate contained 12 experimental units, giving a total of 36 experimental units. The area of each unit was $2 \mathrm{~m} \mathrm{x} 2 \mathrm{~m}$. The distance between two experimental units was $0.5 \mathrm{~m}$, while the distance from one replicate to the other was $1 \mathrm{~m}$. The length and width of the experimental field were $30.5 \mathrm{~m} \mathrm{x} 7 \mathrm{~m}$ respectively, giving a total land area of $213.5 \mathrm{~m}^{2}$. The treatments used were three plant material extracts(i.e. ginger rhizomes, garlic bulbs, and neem leaves), at three different concentrations $(4,8$, and $12 \%$ ), and tap water used as control. 


\section{International Journal of Science and Research (IJSR) \\ ISSN (Online): 2319-7064 \\ Index Copernicus Value (2013): 6.14 | Impact Factor (2015): 6.391}

2.3 Cucumber damping-off and downy mildew diseases conformation assessment

The cucumber field with a previous damping-off and downy mildew history was used in this work. Conformation of the disease was made by isolation from soilfor damping-off disease and leaves for downy mildew disease, followed by identification and pathogenicity tests respectively [7].

\subsection{Preparation of plant material extracts}

The ginger rhizomes, garlic bulbs, and neem leaves were washed separately with tap water, dried under shade, and separately crushed in a mortar with pestle. Distilled water was added to each of the crushed plant material. The mixtures obtained werestirred for 5 minutes and filtered separately through a tripleclean muslin clothes. Three different concentrations of plant material extracts were prepared by extracting 4,8 and $12 \mathrm{~g}$ of each of the plant materials in $100 \mathrm{ml}$ of water to give 4,8 and $12 \%$ concentrations respectively [8].

\subsection{Cucumber seed treatments and soil drenching}

The certified seeds of cucumber ("Poinsett" variety) were soaked in different concentrations (4, 8 and 12\%) of the aqueous extracts of each plant material in different sterilized conical flask for 60 minutes [8]. Then the excess extracts were drained off and treated seeds were kept in blotting paper to remove excess moisture from seed surface and allowed to dry at room temperature for $2 \mathrm{hrs}$ before been taking them to the field for sowing. The soil was also drenched with $20 \mathrm{ml}$ extract of different concentrations of the aqueous extracts of each plant material. The seeds treated with distilled water and soil served as control.

\subsection{Field planting and cultural practices}

Treated cucumber seeds were planted on raised beds $(2 \mathrm{~m} \mathrm{x}$ $2 \mathrm{~m})$ prepared after the experimental field was manually cleared. The seeds were sown 2 per stand with plant spacing of $50 \mathrm{~cm} \mathrm{x} 50 \mathrm{~cm}$ and in four rows per plot, giving a total of 16 stands. Thinning to one plant per stand was done one week after planting (WAP).The cucumber plants received weekly sprays of the different extracted plant materials at three various concentrations of 4,8 and $12 \%$, at $4 \mathrm{WAP}$ and until one week to harvest period. The fifteen liter knapsack sprayer was used in the spraying and thoroughly rinsed after each spray. One teaspoonful of an emulsifier (morning fresh) was added per knapsack sprayer to make cucumber plant surface water-proof.Weeding was carried out manually as the need arose. NPK $(15: 15: 15)$ fertilizer was applied to the plants at the rate of $150 \mathrm{~kg} \mathrm{ha}^{-1}$ using ring method at $3 \mathrm{WAP}$ and staking was down at 4WAP.Harvesting of cucumber fruits commenced 46 days after planting by hand picking. This was done for 3 more times at 6 day intervals.

\subsection{Data collection}

\subsubsection{Disease parameter assessment}

Data were taken on percent pre-and post-emergence damping-off disease. The number of stands that did not germinate were recorded as pre-emergence damping-off, while the number of those stands that wilted after they have germinated at one (1) week after emergence (WAE), were recorded as post-emergence damping-off.Survival counts were recorded as the number of stands that survive $1 \mathrm{WAE}$ [8]. The percentage downy mildew disease incidence, severity and relative disease control weredetermined after 1 week from the last spray. This is based on the number of leaves which had an angular yellowish to pale green areas on their upper leaf surfaces. The percentage of infected leaves relative to the total number of leaves per plant were considered as percentages of disease incidence (D.I) as given below:

$$
\text { D.I }(\%)=\frac{\text { Number of infected leaves per plant }}{\text { Total number of leaves per plant }} \times \frac{100}{1}
$$

Disease severity (\%) was determined according to the scale of Biswas et al. [9]. Plants of each particular treatment were classified into categories as follows: $0=$ leaves completely healthy; $1=1-2$ spots per leaf; $2=3-5$ spots per leaf; $3=6$ 10 spots per leaf; $4=$ up to 25 percent of the leaf area affected; $5=$ up to 50 percent of the leaf area affected; $6=$ up to 75 percent of the leaf area affected; $7=$ more than 75 percent of the leaf area affected.The percentage of disease severity (D.S) for each particular treatment was calculated using the following formula:

$$
\text { D.S }(\%)=\frac{\Sigma(\text { Number of infected leaves in each grade } \times \text { the representative value of each grade })}{[\text { Total no. of leaves observed per plant } \times \text { the representati ve value of the highest grade }(7)]} \times \frac{100}{1}
$$

The percentage relative disease control (R.D.C) was calculated as disease severity of treatment to disease severity of check, as given below:

$$
\text { R.D.C }(\%)=\left[1-\left(\frac{\text { Disease severity of the treatment }}{\text { Disease severity check }}\right)\right] \times \frac{100}{1}
$$

\subsubsection{Vegetative parameters}

The vine lengths were measured from the base to the apex of the plant and the number of leaves was counted on a weekly basis starting from the 5 to 8 WAP and the average recorded.

\subsection{Statistical analysis}

Data were subjected to analysis of variance (combined for the two years) to determine any significant effects of the different treatments. The treatment means were compared using the least significant difference (LSD) test at a significance level of 0.05 . Normality of distributions and homogeneity of variances for disease parameters was assessed before conducting any statistical analysis. Statistical analyses were performed using GenStat Discovery Edition software version 3.0 for Windows [10].

\subsubsection{Yield parameters}

The number and fresh weight $(\mathrm{kg})$ of fruits harvested per plot were recorded and average per plant taken. 


\section{International Journal of Science and Research (IJSR) \\ ISSN (Online): 2319-7064}

Index Copernicus Value (2013): 6.14 | Impact Factor (2015): 6.391

\section{Results and Discussion}

The analysis of variance for the combined two years field trials revealed that the three plant material extracts (i.e. garlic bulbs, ginger rhizomes, and neem leaves) used as seed treatments and as sprays at various concentrations $(4,8$, and $12 \%$ ) had significant main effects on all the parameters measured compared to control treatment (Table 1).

Table 1: Statistical significance of the ANOVA of different plant extracts at various concentrations used as seed treatments and soil drench on pre-and post-emergence damping-off and survival counts, and as sprays on disease incidence, disease severity and relative decease control, vine length and number of leaves per plant, number of fruits per plant and fruit weight per plant of cucumber (pooled data of

\begin{tabular}{|c|c|c|c|}
\hline Parameters & $\begin{array}{c}\text { Plant } \\
\text { extracts }\end{array}$ & Levels & Interaction \\
\hline $\begin{array}{c}\text { Pre-emergence damping-off } \\
(\%)\end{array}$ & $0.000 * * *$ & $0.006^{* *}$ & $0.911^{\mathrm{NS}}$ \\
\hline \begin{tabular}{|c|} 
Post-emergence damping-off \\
$(\%)$
\end{tabular} & $0.000 * * *$ & $0.031^{*}$ & $0.071^{\mathrm{NS}}$ \\
\hline Survival counts $(\%)$ & $0.030 * *$ & $0.042 *$ & $0.936^{\mathrm{NS}}$ \\
\hline Disease incidence (\%) & $0.000 * * *$ & $0.002 * *$ & $0.128^{\mathrm{NS}}$ \\
\hline Disease severity (\%) & $0.000 * * *$ & $0.004 * *$ & $0.399^{\mathrm{NS}}$ \\
\hline Relative disease control (\%) & $0.000 * * *$ & $0.007 * *$ & $0.073^{\mathrm{NS}}$ \\
\hline Vine length $(\mathrm{cm})$ & $0.017 *$ & $0.005 * *$ & $0.054^{\mathrm{NS}}$ \\
\hline Number of leaves plant $^{-1}$ & $0.001 * *$ & $0.015^{*}$ & $0.093^{\mathrm{NS}}$ \\
\hline Number of fruits plant $^{-1}$ & $0.003 * *$ & $0.023 *$ & $0.037^{\mathrm{NS}}$ \\
\hline \begin{tabular}{|c|} 
Fruit weight plant \\
${ }_{1}^{-1}$ )
\end{tabular} & $0.022 *$ & $0.003^{* *}$ & $0.069^{\mathrm{NS}}$ \\
\hline
\end{tabular}

significant difference at $\mathrm{P}<0.05, \mathrm{P}<0.01$ or $\mathrm{P}<0.001$

respectively; Values are mean of three replicates $(n=3)$.

\subsection{Damping-off disease}

Plant extractsused as seed treatments and soil drench significantly suppressed the pre-and post-emergence damping-off disease and thus increased the survival counts, relative to control treatment. Ginger extract was more effective than neem and garlic extracts respectively, while neem extracts were better than that of garlic extract (Fig. 1A). The effects were also positively influenced atvarious concentrations, although there was no linear relationship between plant extract concentrations and efficacy (Fig. 1B). Plant extracts at $12 \%$ concentration showed an increase in the pre-and post-emergence damping-off, and reduction in the survival counts, compared with other concentrations $(4 \%$ and $8 \%$ ). When plant extracts were used at lower concentrations $(4 \%$ or $8 \%)$, better results were recorded. The percentage of survived plants wereincreased, by increasing plant extract concentration from 4 to $8 \%$ (Fig. 1B). The degree of effectiveness of plant extracts to reduce dampingoff disease of cucumber and increase the survival counts, which were in order of ginger $>$ neem $>$ garlic, is in agreement with the findings by Abd-El-Moity and Shatla[11] who reported that ginger extract had thehighest suppressive effect on Rhizoctonia solani, a damping-off pathogen, when added to the infected medium. This effect might be due to the presence of certain disulfide amino-acid in ginger extract [11]. Kurucheve and Padmauath [12] equally supported the observation of [11] that ginger extract contains well specialized materials which inhibit the activity of hydrolytic

\section{A. Plant extracts main effect}

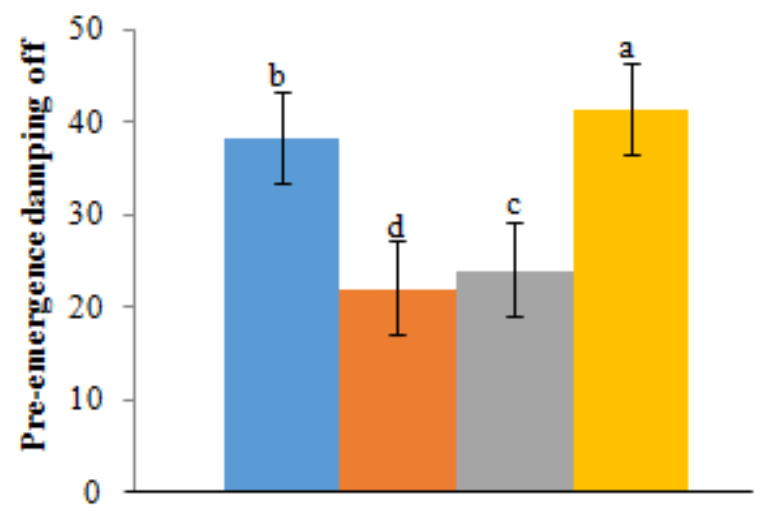

B. Concentrations main effect

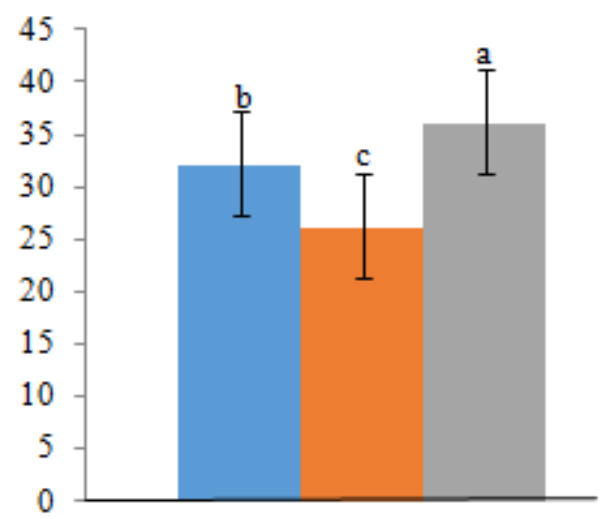


International Journal of Science and Research (IJSR)

ISSN (Online): 2319-7064

Index Copernicus Value (2013): 6.14 | Impact Factor (2015): 6.391
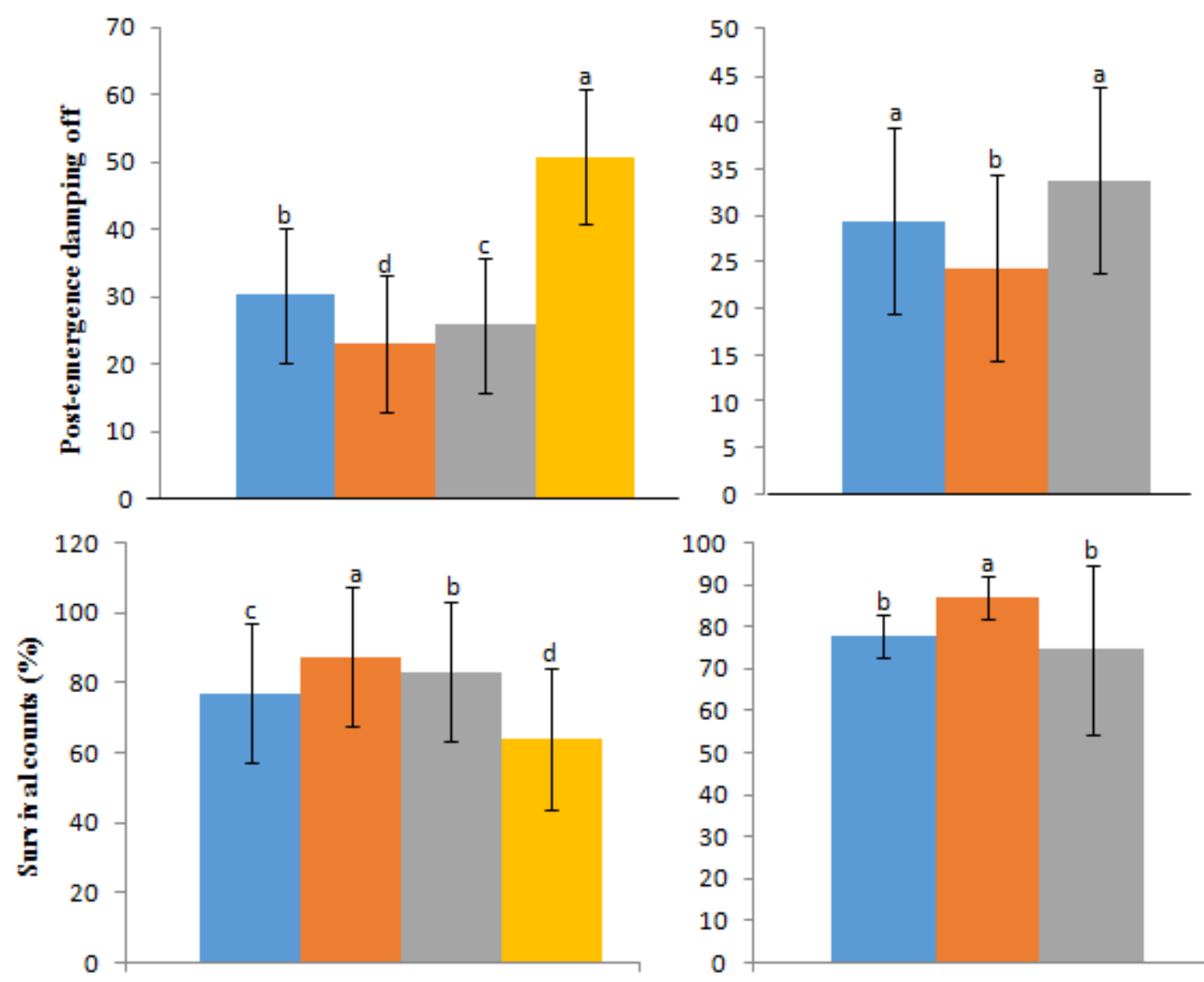

Plant extracts

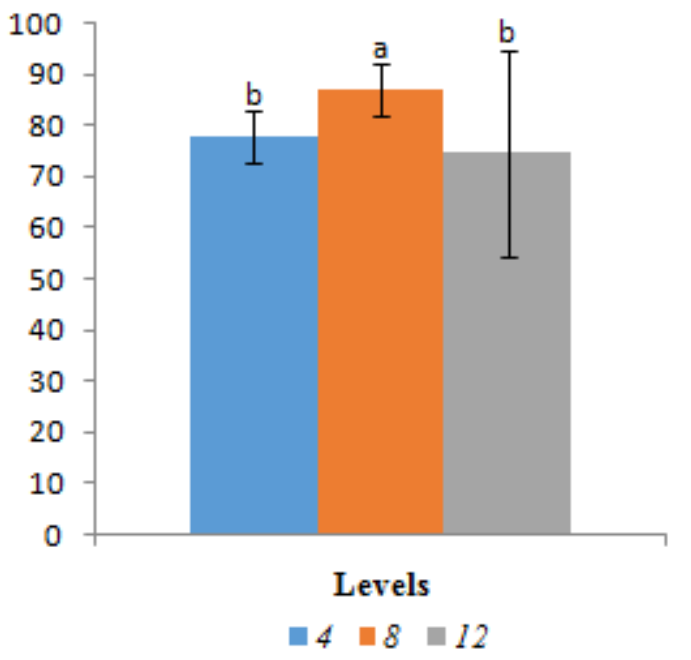

Figure 1: Main effects of plant extracts (A) and different concentrations (B) on the pre-and post-emergence damping-off and survival counts $(\%)$ of cucumber. Means $(n=3)$ that do not share a letter differed significantly at $\mathrm{P}<0.05$ (pooled data of two years)

enzymes produced by the pathogen. This work is equally in conformity with the report of Tohamyet al.[8] who observed that extract of ginger cloves was the most effective in inhibiting percentage of damping-off disease infection.Concentration level at $8 \%$ gave the highest suppressive effect on pre-and post-emergence damping off disease, followed by $4 \%$, while $12 \%$ was the least. This implies that concentration level at $8 \%$ produced the highest percentage survival counts. This is in conformity with the report of Dwived and Singh [13], who observed that the percentage pre-and post-emergence damping off were decreased by increasing the concentration from $3 \%$ to $6 \%$. They concluded that this might be due to more active ingredient in plant extract at increased concentration. The least effect produced by $12 \%$ concentration might be that over dosage of the active ingredient had no effect on disease management.

\subsection{Disease status and relative disease control}

Plant extract treatments at various concentrations significantly reduced the percentage incidence and severity of downy mildew disease and thus enhanced the relative disease control compared with control treatments (Fig. 2A and Fig. 3B). The plants sprayed with ginger extracts at weekly intervals exhibited the greatest effect, followed by that of neem and least was that of garlic. The effects were significantly better at $8 \%$ concentration, compared with 4 and $12 \%$ in terms of disease status (Fig. 2B) and relative disease control (Fig. 3B) respectively. This result confirms the finding of Solufeed [14] that weekly foliar sprays of the extract of ginger reduced the incidence and severity of downy mildew disease. The highest downy mildew disease incidence and severity as a result of garlic extract spray reported in this research in relation to other plant extracts is in contradiction to the work of Portz et al. [15]. They observed that the volatile anti-microbial from garlic, at concentrations of $50-1000 \mathrm{ugmL}^{-1}$, reduced the severity of Pseudoperospora cubensis on cucumber by approximately $50-100 \%$. The non-conformity of the results of this field trials with the report of [15] may be due to concentration difference.

\subsection{Growth and yield}

Different plant extract treatments significantly altered the growth and yield of cucumber plants to all concentrations tested. The vine length and number of leaves per plant were considerably higher in the plants sprayed with different extracts when compared with the control treatments regardless of concentrations (Table 2). The degree of effectiveness of plant extracts sprays was in the order of 


\section{International Journal of Science and Research (IJSR) \\ ISSN (Online): 2319-7064}

Index Copernicus Value (2013): 6.14 | Impact Factor (2015): 6.391

ginger followed by neem and then garlic. Similarly, number of fruits and weight of fruits per plant were significantly better in the plant sprayed with garlic extracts than in the control treatment, but were greater in the treatment with neem, which was further enhanced with the ginger extract treatment at various concentrations (Table 2). Concentrations of different plant extracts also had significant effects on plant growth and yield of cucumber plants. The vine length, number of leaves, number and weight of fruits per plant were considerably higher in the plants sprayed with $8 \%$ concentration, which differed significantly from the rest of concentrations, except for weight of fruits per plant where it showed statistical similarity with $4 \%$ concentration (Table 2). This is in agreement with the work of Tohamyet al. [13], who observed that ginger extract significantly improved number of the leaves per plant, number of flowers per plant, shoot and root length, and fresh and dry weight of shoot and root system compared with non-sprayed plant (i.e. control). Also, Solufeed [14] reported that weekly foliar sprays of the extract of ginger had a beneficial effect on cucumber yields.

\section{Conclusion and Recommendation}

The results of the combined two yearsfield trials have shown that different plant extracts at various concentrations used as botanicals for seed treatments, soil drench and as sprays had a positive effect on the management of damping-off and downy mildew disease of cucumber. Ginger extract gave the

\section{A. Plant extracts main effect}
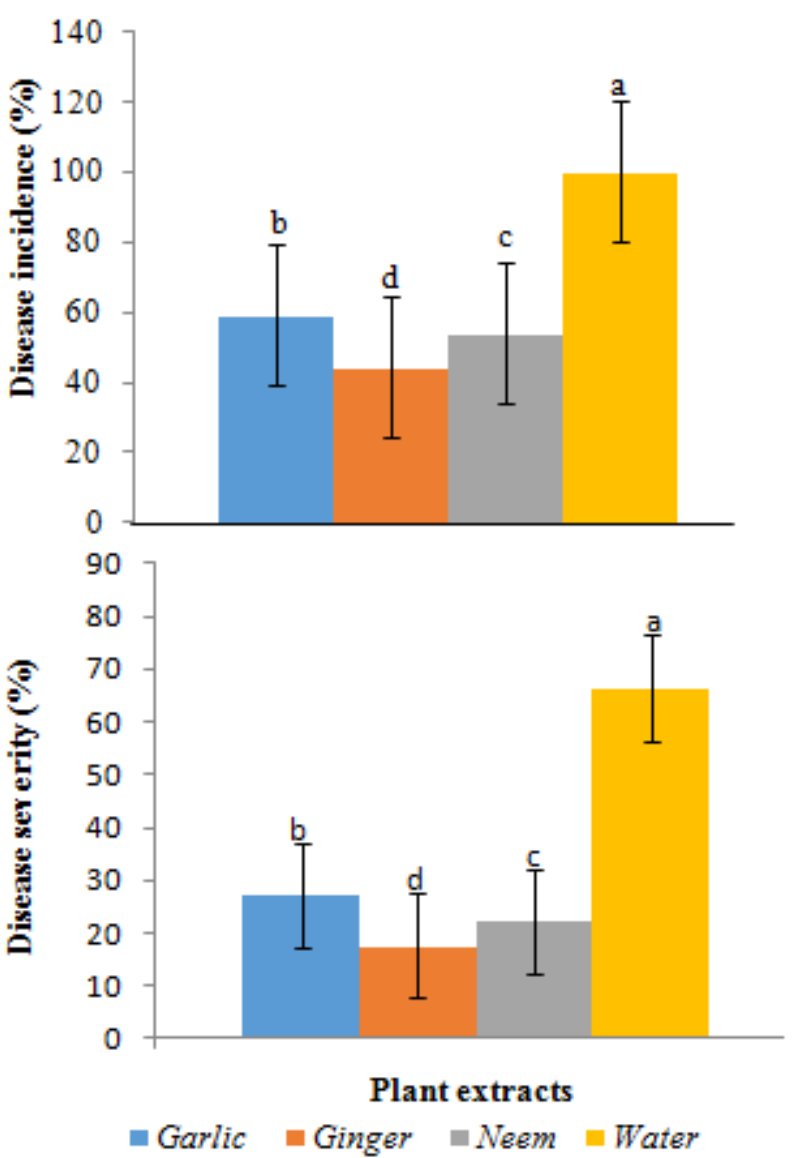

highest suppressive effect on damping-off disease and increase the survival counts. It also reduces the incidence and severity of downy mildew disease and thus enhances the relative disease control. This resulted in improved growth and yield of cucumber plant when compared with other treatments. Neem and garlic extracts can also be used to manage damping-off and downy mildew disease of cucumber in relation to check, but not as effective as ginger extract at all concentrations tested. The concentration levels of plant extracts also had a significant effect on the management of damping-off and downy mildew disease and enhancement of the survival counts and the relative disease control respectively. The concentration of $8 \%$ gave the highest suppressive effect, compared to other concentrations $(4 \%$ or $12 \%)$. It may therefore be recommended that cucumber producers in Abakaliki, South Eastern Nigeria should apply ginger extract at $8 \%$ concentration as ecofriendly botanical alternative, for management of dampingoff and the downy mildew diseases.

\section{Acknowledgement}

I acknowledge the effort of Okpani Florence M. and Nwosu, Ozioma I., who ensured that this research work was accomplished.

\section{B. Concentrations main effect}
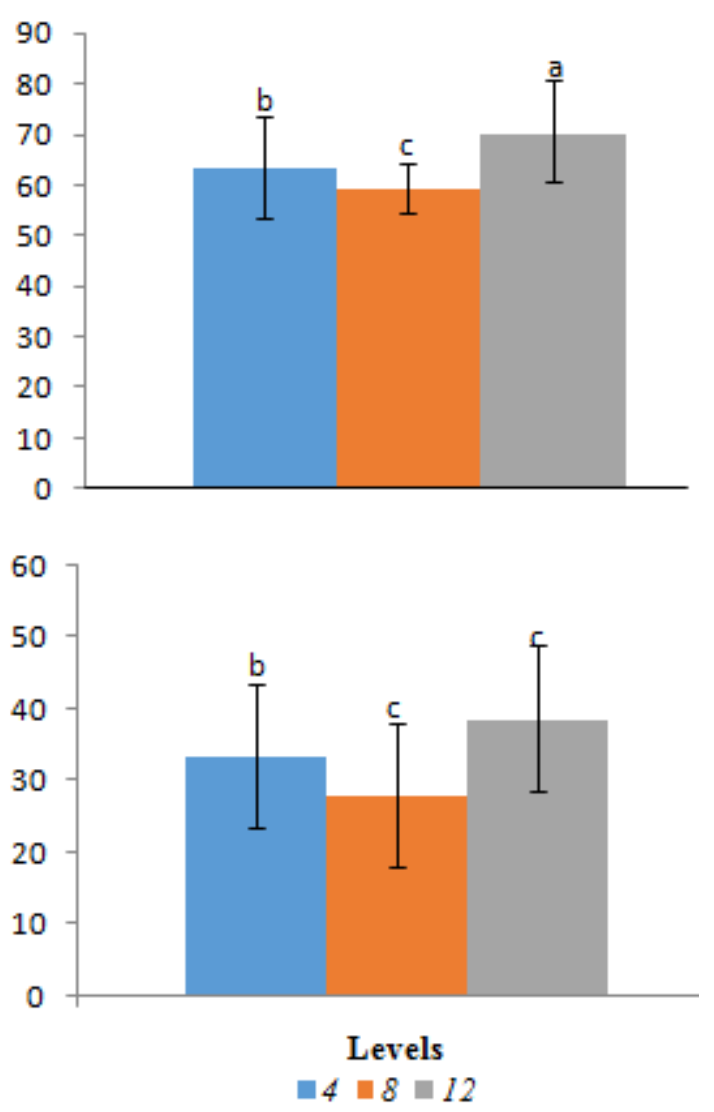

Figure 2: Main effects of plant extracts $(\mathrm{A})$ and different concentrations $(\mathrm{B})$ on the percentage disease incidence and disease severity of cucumber. Means $(n=3)$ that do not share a letter differed significantly at $\mathrm{P}<0.05$ (pooled data of two years) 
International Journal of Science and Research (IJSR)

ISSN (Online): 2319-7064

Index Copernicus Value (2013): 6.14 | Impact Factor (2015): 6.391

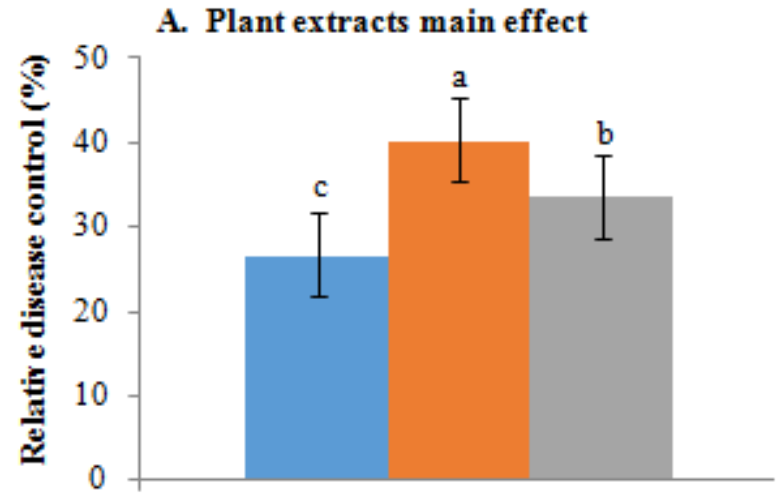

Plant extracts

Garlic $\quad$ Ginger $\quad$ Neem
B. Concentrations main effect

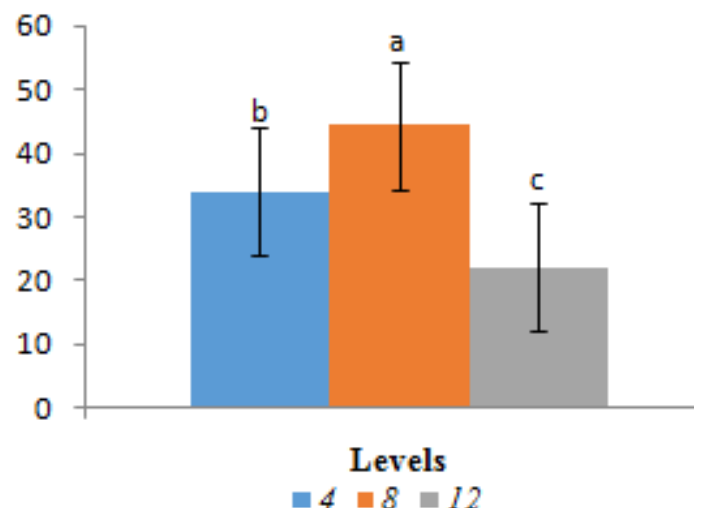

Figure 3: Main effects of plant extracts (A) and different concentrations (B) on the percentage relative disease controlof cucumber. Means $(\mathrm{n}=3)$ that do not share a letter differed significantly at $\mathrm{P}<0.05$ (pooled data of two years).

Table 2: Main effects of plant extracts and concentration levels on the growth and yield of cucumber (pooled data of two years)

\begin{tabular}{|c|c|c|c|c|}
\hline $\begin{array}{c}\text { Plant } \\
\text { extracts }\end{array}$ & $\begin{array}{c}\text { Vine } \\
\text { length } \\
(\mathrm{cm})\end{array}$ & $\begin{array}{c}\text { No. of } \\
\text { leaves }\end{array}$ & $\begin{array}{c}\text { No. of } \\
\text { fruits/plant }\end{array}$ & $\begin{array}{c}\text { Wt. of } \\
\text { fruits/plant } \\
(\mathrm{kg} / \mathrm{plant})\end{array}$ \\
\hline Garlic & $95.41 \mathrm{~b}$ & $24.59 \mathrm{c}$ & $9.23 \mathrm{a}$ & $3.067 \mathrm{~b}$ \\
\hline Ginger & $101.62 \mathrm{a}$ & $27.34 \mathrm{a}$ & $10.04 \mathrm{a}$ & $3.518 \mathrm{a}$ \\
\hline Neem & $97.43 \mathrm{~b}$ & $25.87 \mathrm{~b}$ & $9.52 \mathrm{a}$ & $3.183 \mathrm{~b}$ \\
\hline Water & $82.99 \mathrm{~d}$ & $22.75 \mathrm{~d}$ & $7.43 \mathrm{~b}$ & $2.267 \mathrm{c}$ \\
\hline LSD $(0.05)$ & 2.309 & 1.076 & 1.289 & 0.1216 \\
\hline Sig. & $*$ & $* *$ & $* *$ & $*$ \\
\hline Levels & & & & \\
\hline 12 & $91.80 \mathrm{~b}$ & $23.25 \mathrm{c}$ & $8.82 \mathrm{~b}$ & $2.613 \mathrm{cs}$ \\
\hline 8 & $98.92 \mathrm{a}$ & $27.64 \mathrm{a}$ & $10.10 \mathrm{a}$ & $2.843 \mathrm{~b}$ \\
\hline 4 & $92.48 \mathrm{~b}$ & $24.53 \mathrm{~b}$ & $8.34 \mathrm{~b}$ & $2.841 \mathrm{~b}$ \\
\hline LSD $_{(0.05)}$ & 1.268 & 1.165 & 1.116 & 0.5750 \\
\hline Sig. & $* *$ & $*$ & $*$ & $* *$ \\
\hline
\end{tabular}

Means with the same letter are not significantly different at $5 \%$ by DMRT; *** significant difference at $P<0.05$, and $P<0.01$ respectively; Values are mean of three replicates $(n=3)$.

\section{References}

[1] Ehigiator, J.O., Ariyo, A.D. and Imasuen, E.E. Soil fertility and nutritional studies on citrus, fruit and vegetable crops in Nigeria (1975 to 2005). Nigerian Journal of Agriculture, Food and Environment, 11(2):103-114, 2015.

[2] Mohamed, A., Hamza, A. and Derbalah, A. Recent approaches for controlling downy mildew of cucumber under greenhouse conditions. Plant Protect. Sci., 52: 19, 2016.

[3] Abdel-Kader, M.M., El-Mougy, N.S., Aly, M.D.E., Lashin, S.M. and Abdel-Kareem, F. Greenhouse Biological Approach for Controlling Foliar Diseases of Some Vegetables.2012.

[4] Gurjar1, M.S., Ali, S., Akhtar, M. and Singh, K.S. Efficacy of plant extracts in plant disease management. Agricultural Sciences, 3(3): 425-433, 2012. http://dx.doi.org/10.4236/as.2012.33050

[5] Chandrashekhara, S., Niranjan Raj, G., Manjunath, S.D. and Shekar Shetty, H. Seed treatment with aqueous extract of Viscum album induces resistance to pearl millet downy mildew pathogen, Journal of Plant Interactions, 5:4, 283-291, 2010.

[6] Akinsanmi, O. Certificate Agricultural Science. Longman, Nigeria. Pp 104-112, 1975.

[7] Aly, A.Z., Tohamy, M.R.A., Abd-El-Moity, T.H., Atia, M.M.M. and Abed-El-Moneim, M.L. Role of organic matter in controlling some soil borne and foliage disease of cucumber. Internat. Sympos. The Horizons of using Organic Matter and Substrates in Horticulture. Cairo, Egypt. 2002.

[8] Tohamy, M.R.A.,Aly, A.Z.,Abd El-Moity T.H. and Abd-El-Moneim (Maisa), L. Evaluation of some plant extracts in controlling damping-off and mildew diseases of cucumber. Egypt J. Phytopathol., (2):71-80, 2002.

[9] Biswas, S., Teotia, R.S. and Manal, S.K. Some field observations on the severity of powdery mildew (Phyllactinia corylea) inmulberry. Indian J. Sci., 31: 6769, 1992.

[10] GenStat Inc. GenStat Discovery Edition 3. - VSN International Ltd.2008.

[11] Abd-El-Moity, T.H. and Shatla, M.N. Biological control of white rot disease of onion Sclerotium cepivorum by Trichoderma harzianum. Phytopathology Z., 100: 2935, 1981.

[12] Kurucheve, V. and Padmavathi, R. Fungi toxicity of selected plant products against Pythium aphanidermatum. Indian Phytopathol., 50: 529535,1997. (c.f. Rev. Pl. Pathol., 78:1370).

[13] Dwived, S.K. and Singh, K.P.Fungi toxicity of some higher plant products against Macrophomia phaseolina (Tassi) Gold. Flavour and Fragrance J., 13:397-399, 1998. (c.f. Rev. Pl. Pathol., 78:3082).

[14] Solufeed.Garlic extracts literature review. Technical essentials Solufeed Ltd. www.solufeed.com. Pg. 1-5, 2015.

[15]Portz, D., Koch, E. and Slusarenko, A.J. Effects of garlic (Allium sativum) juice containing allicin on Phytophthora infestans and downy mildew of cucumber caused by Pseudoperonospora cubensis. Eur J Plant Pathol., 122:197-206, 2008. 